\title{
Konfunder - ikke confounder - på norsk
}

\author{
Et av de viktigste begrepene i epidemiologi er «confounder». På norsk bør det skrives «konfunder».
}

Når noen påstår at en faktor A er årsak til en effekt $\mathrm{B}$, lurer vi på om det finnes en faktor som kan påvirke både $\mathrm{A}$ og $\mathrm{B}$ og derved tilsløre en reell årsakssammenheng (1). Denne faktoren kalles på engelsk «confounder» eller «confounding factor». Det dreier seg om kjente eller ukjente bakenforliggende forhold som kan påvirke utfallet og som er ulikt fordelt mellom eksponerte og ikke-eksponerte (2). Eksempel: Er vindrikking (faktor A) årsak til bedre helse (effekt B)? Kanskje, men det finnes selvsagt en rekke bakenforliggende variabler, f.eks. sosial klasse, som kan være den egentlige forklaringen.

Vi kan også snakke om spuriøs sammenheng. Det er betegnelsen på en skinnsammenheng som fremstår som ekte årsakvirkning-forhold, men ikke er det. Det er en bakenforliggende variabel, en «confounder», som er den egentlige årsaken til sammenhengen $(3,4)$.

\section{Oversettelser}

En rekke norske oversettelser for «confounder» har vært foreslått: forvirringsfaktor, konfusor, tilsløringsfaktor $(1,5)$, tredjevariabelsfeil (4), effektforveksler (6) og justeringsvariabel (Geir Jacobsen, personlig meddelelse). På svensk har man kalt det for förväxlingsfaktor (7).

Steinar Westin mente i Språkspalten i 2000 at «konfundering» lyder greit på norsk: «Som substantiv burde også en konfunder ha rimelig sjanse, som kortform av konfunderende faktor» (1). Tiden har gitt ham rett. Konfundering er nå skrivemåten i flere norske lærebøker (8-10). Det er da også logisk, ettersom vi på norsk allerede har verbet «konfundere», som betyr «forvirre, gjøre forvirret» (11).

Det finnes eksempler på formen «konfunderer», i flertall «konfunderere». En parallell til dette er betablokkerer, som nok er den språklig korrekte betegnelsen, men det er kortformen betablokker som har slått igjennom (12). Jeg tror «konfunderer» blir for tungvint i bruk. Selv om man kanskje ikke skulle tro det, ønsker vi mennesker i utpreget grad å spare talemuskulaturen.

Hva så med andre norske oversettelser, slik som tredjevariabelsfeil, effektforveksler eller justeringsvariabel? De er ikke dårlige, men ingen av dem er særlig brukt, og det vil være tyngre å få slike nye

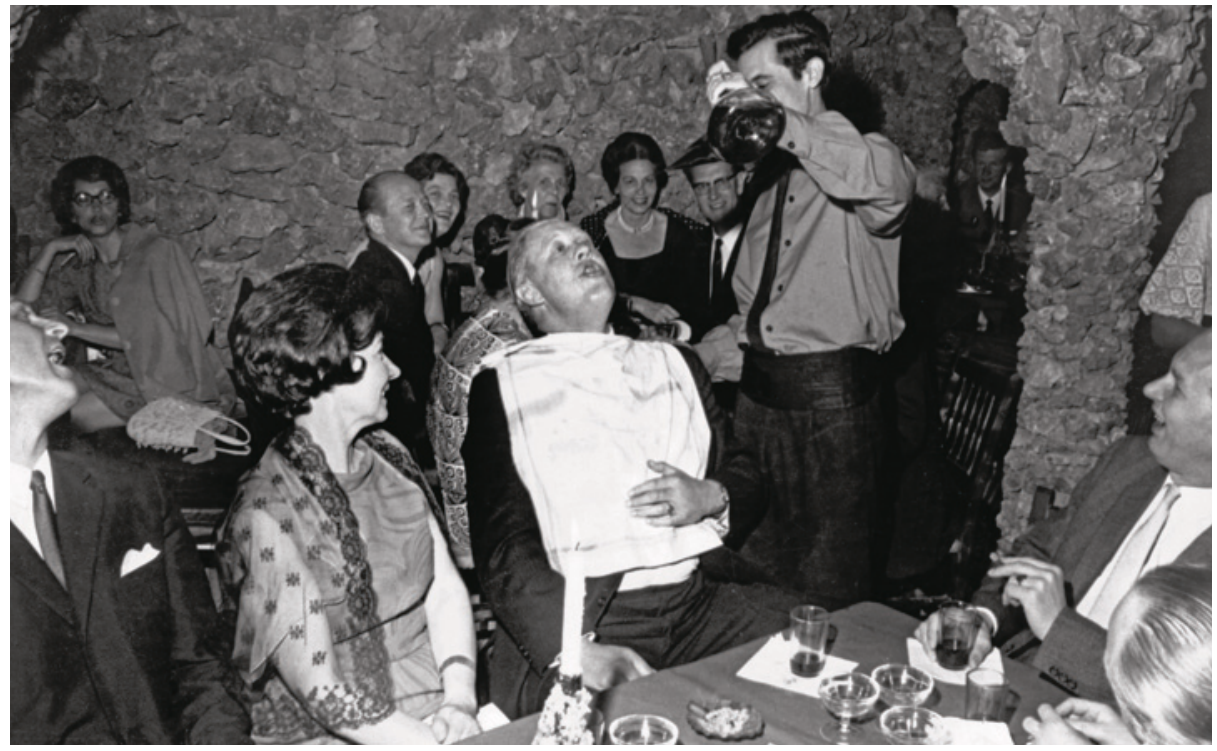

Er vindrikking årsak til bedre helse - eller er det en spuriøs sammenheng? Bildet viser noen av de første norske sydenturistene på Mallorca i 1967. Ifølge bildeteksten hygger de seg med vindrikking av flaske på en grisefest. Foto NTB scanpix

begreper i bruk, både fordi de føles fremmede og fordi det ikke er selvinnlysende at det er «confounder» vi snakker om. Med konfunder vil man kunne bruke det som det er, uten å måtte legge til en forklaring bak. Eventuelt kan man bruke «bakenforliggende forklaringsfaktor» i parentes bak konfunder, men da som en forklaring og ikke erstatning.

\section{Konklusjon}

Konfunder bør anvendes som norsk oversettelse av «confounder». Skrivemåten har gode muligheter til å bli brukt, fordi den er så lett å kjenne igjen fra den engelske originalen at den ikke trenger en særskilt forklaring. Det er i praksis også den foretrukne formen i Tidsskriftet og i viktige lærebøker de senere årene. Søk på tidsskriftet.no gir 32 treff på ordet «konfunder» (1.8. 2013). Nå skal det også inn som oppslagsord i Tidsskriftets ordliste (13).

\section{Erlend Hem}

erlend.hem@medisin.uio.no

Erlend Hem (f. 1970) er dr.med. og assisterende sjefredaktør i Tidsskriftet.
Litteratur

1. Westin S. Forvirring eller tilsløring - eller rett og slett konfundering? Tidsskr Nor Lægeforen 2000; 120: 122

2. Westin S. Epidemiologien og jakten på det gode liv. Tidsskr Nor Lægeforen 1998; 118: 517-8. http://tidsskriftet.no/legacy/199804/leder3.html (1.8.2013).

3. Godal AM. Spuriøs. I: Store norske leksikon. http://snl.no/spuri \%C3\%B8s (1.8.2013).

4. Magnus P, Bakketeig LS. Epidemiologi. 3. utg. Oslo: Gyldendal, 2003: 96-8.

5. Vogt J.Forvirringsfaktorer. Tidsskr Nor Lægeforen 2000; 120: 122

6. Hem E. Mors alder, fødselsrekkefølge og selvmord. Tidsskr Nor Legeforen 2013; 133: 742

7. Pettersson A, Gordon M, Edgren G et al. Biostatistik har en central roll i epidemiologi. Introduktion till begrepp och metoder utifrån kliniska observationella studier. Läkartidningen 2013; 110: 470-4. www.lakartidningen.se/engine. php?articleld= 19333 (1.8.2013)

8. Thelle DS. Innføring i epidemiologi. Oslo: Cappelen Akademisk, 1998: 90-2.

9. Laake P, Hjartåker A, Thelle DS et al. red. Epidemiologiske og kliniske forskningsmetoder. Oslo: Gyldendal Akademisk, 2007: 80.

10. Laake P, Olsen BR, Benestad HB. red. Forskning i medisin og biofag. 2. utg. Oslo: Gyldendal Akademisk, 2008: 124

11. Konfundere. I: Store norske leksikon http://snl.no/konfundere (1.8.2013)

12. Hem E. Betablokker eller betablokkerer? Tidsskr Nor Legeforen 2013; 133: 859.

13. Ordliste. Forfatterveiledningen. Tidsskrift for Den norske legeforening. http://tidsskriftet.no/Innhold/ Forfatterveiledningen/Spraak/Ordliste (1.8.2013). 